Arq. Bras. Med. Vet. Zootec., v.56, n.3, p.320-324, 2004

\title{
Serum and urinary measurements of prostatic acid phosphatase (PAP) and prostatic specific antigen (PSA) in dogs
}

\author{
[Mensurações sérica e urinária de fosfatase ácida prostática e antígeno prostático específico em cães] \\ R.L. Amorim, V.M.B.D. Moura, G.W. Di Santis, E.P. Bandarra, C. Padovani \\ ${ }^{1}$ Departamento de Clínica Veterinária da Faculdade de Medicina Veterinária e Zootecnia - UNESP - Botucatu \\ Distrito de Rubião Jr., s/n \\ 18618-000 - Botucatu, SP \\ ${ }^{2}$ Instituto de Biociências - UNESP - Botucatu
}

\begin{abstract}
Serum and urinary prostatic acid phosphatase (PAP) and prostatic specific antigen (PSA) from 20 dogs were measured. PAP and PSA tests were carried out in authomatized equipment with commercial kits used for humans. Mean PAP serum value was $0.7 \mathrm{U} / 1$ and urinary $0.1 \mathrm{U} / 1$. Mean serum and urinary PSA were $0.005 \mathrm{ng} / \mathrm{dl}$ and $0.004 \mathrm{ng} / \mathrm{dl}$, respectively. In vivo determination of these two biomarkers in dogs is a new form of diagnosis in veterinary medicine and these values should be correlated with the morphological lesion of the prostate gland.
\end{abstract}

Keywords: dog, prostatic acid phosphatase, PAP, prostatic specific antigen, PSA

\section{RESUMO}

Realizaram-se mensurações sérica e urinária de fosfatase ácida prostática $(P A P)$ e antígeno prostático especifico (PSA) de 20 cães. Os testes de PAP e PSA foram feitos em um equipamento automatizado, com o uso de kits comerciais para humanos. A média de PAP sérico foi de 0,7U/l e urinário 0,U/l. As médias do PSA sérico e urinário foram 0,005ng/dL e 0,004ng/dl, respectivamente. A determinação do dois biomarcadores in vivo é uma nova opção de diagnóstico na medicina veterinária e os valores obtidos devem ser correlacionados com a lesão morfológica da próstata.

Palavras-chave: cão, fosfatase ácida prostática, PAP, antígeno prostático específico, PSA

\section{INTRODUCTION}

Prostatic diseases are frequent in older dogs. The prostate gland increases in size and weight, more frequently due to a hyperplasia or a neoplasia, as the animal gets older (Barsanti and Finco, 1989).
A dog's prostate gland is the best natural model for the study of human prostate diseases, for similarities in the development of benign prostatic hyperplasia (BPH) and neoplasia (McEntee et al., 1987; Lowseth et al., 1990; Karr et al., 1995).

Apoio financeiro: Fundação de Apoio à Pesquisa do Estado de São Paulo.

Recebido para publicação em 18 de março de 2003.

Recebido para publicação, após modificações, em 17 de setembro de 2003.

E-mail: renee@fmvz.unesp.br 
Due to the high frequency of prostatic lesions in dogs, "in vivo" diagnostic methods should be established in order to determine the specific lesion, treatment and prognosis. The human prostate gland secretes many glycoproteins. In the past years, two of them have been used for the identification of cancer: prostatic acid phosphatase (PAP) and prostatic specific antigen (PSA) (McEntee et al., 1987).

Similarly to humans, prostatic acid phosphatase is hormone dependent, and its levels are variable with age. Quantitative changes in canine PAP are less remarkable than in humans, nevertheless they are important in the evaluation of the prostatic epithelial cells secretory activity (Aumüller et al., 1987).

In humans, PAP serum levels can be useful in the diagnosis of prostate adenocarcinoma that are actively growing, and can metastasize to local lymph nodes or bones. PAP should not be considered a specific marker for prostatic disease, since its levels are high in gastrointestinal tract cancer, $\mathrm{BPH}$, inflammation of the prostate and after prostatic massage (Corazza et al., 1994).

In 1979, Wang discovered PSA in serum of human patients with prostate cancer (apud Alivizatos et al., 1992). This enzyme is secreted in the prostatic fluid in concentrations higher than $3.6 \mathrm{mg} / \mathrm{ml}$, and it is identified in the rough endoplasmatic reticulum and cytoplasmatic vesicles of epithelial prostatic cells. The secretion of PSA is hormone related (McEntee et al., 1987).

As in 10 to $40 \%$ of human patients with $\mathrm{BPH}$, PSA levels are high, there is some concern about the use of PSA as an indicator of prostatic cancer (Alivizatos et al., 1992; Christensson et al., 1993). PSA levels ranging from 4 to $10 \mathrm{ng} / \mathrm{mL}$ are difficult to interpret, as they can indicate BPH or neoplasia (Aus et al., 1994).

PSA is only produced by prostatic epithelial cells and is eliminated in the urethra; therefore urinary measurement of PSA is suggested (White et al., 1992). These authors studied PSA levels in fresh and frozen urinary samples, and could not find differences in their values. They also found that more alkaline urine tends to have higher PSA levels (White et al., 1992).
PAP specificity is greater than PSA, and PSA dosage is more sensitive than PAP, as PSA is a smaller molecule (Stamey et al., 1987; Alivizatos et al., 1992) that drains more easily through the basal membrane of prostatic acinar cells (Armbruster, 1993).

Once PSA was chosen for the early detection of human prostate cancer, the idea whether it might work in other species was suggested. Using Southern blot analyses, PSA related genes were recognized in primates, but not in other mammals (Karr et al., 1995).

In dogs, a worse prognosis of prostatic cancer can be due to its late diagnosis, as there are no serum biomarkers, such as PSA, available for the detection of early cancer (Waters and Bostwick, 1997a,b). The aim of this work was to evaluate serum and urinary levels of PAP and PSA in dogs, as an in vivo diagnostic tool for prostatic disease.

\section{MATERIAL AND METHODS}

Blood, urine and prostatic biopsy samples were collected from twenty male dogs, older than four years, with no breed predilection, and no history of prostatic disease.

Blood samples were drawn from the jugular vein into Vacutainer ${ }^{1}$ tubes. They were centrifuged for 15 minutes at $1500 \mathrm{rpm}$ and the serum was stored in eppendorf tubes at $-20^{\circ} \mathrm{C}$ until PAP and PSA measurement.

Urine samples were collected with vesical tubes, connected to a $10 \mathrm{ml}$ syringe, and $500 \mu$ l of urine was frozen in Eppendorf tubes. The serum and urine samples for PAP dosage received a drop of acetic acid (number 4 reagent of the dosage kit), so that they could be maintained frozen until processing.

For PAP measurement, a colorimetric ${ }^{2}$ automation equipment with a commercial $\mathrm{kit}^{3}$ for dosage of total acid and prostatic phosphatase was used. Serum and urinary dosages of PSA

\footnotetext{
${ }^{1}$ SST Gel and clot activator, Becton Dickinson

${ }^{2}$ Technicon-RA-XT

${ }^{3}$ Biotrol Pac monoreactif, A03034, Biotrol Diagnostic, France.
} 
were carried out in anautomated chemiluminescence equipment ${ }^{4}$ using a commercial kit for total PSA dosage ${ }^{5}$. Spearman test was used to verify whether there was a correlation between the serum and urinary values of PAP and PSA.

In order to compare the values of these enzymes with those found by other authors, the animals were divided in two groups according to their ages; group 1 from four to six years of age and group 2 from seven to 11 years.

\section{RESULTS}

In Table 1, the mean, minimum and maximum values of PSA and PAP of the animals can be found.
Table 1. Mean, minimum and maximum values of serum and urinary prostatic acid phosphatase (PAP) and prostatic specific antigen (PSA) in dogs

\begin{tabular}{lcc}
\hline Variable & Serum & Urinary \\
\hline AP (U/l) & $0.700 \pm 0.888$ & $0.100 \pm 0.175$ \\
& $(0.100$ & $2.900)$ \\
PSA (ng/dl) & $0.005 \pm 0.0020$ & $0.004 \pm 0.0026$ \\
& $(0.000 ; 0.009)$ & $(0.000 ; 0.0220)$ \\
\hline
\end{tabular}

Fig. 1 and 2 show the correlation between the serum and urinary values of PAP and PSA in group 1 (four to six years old) and 2 (seven to 11 years old).

To evaluate the association between the serum and urinary values of PAP and PSA, Spearman test was used (Table 2).

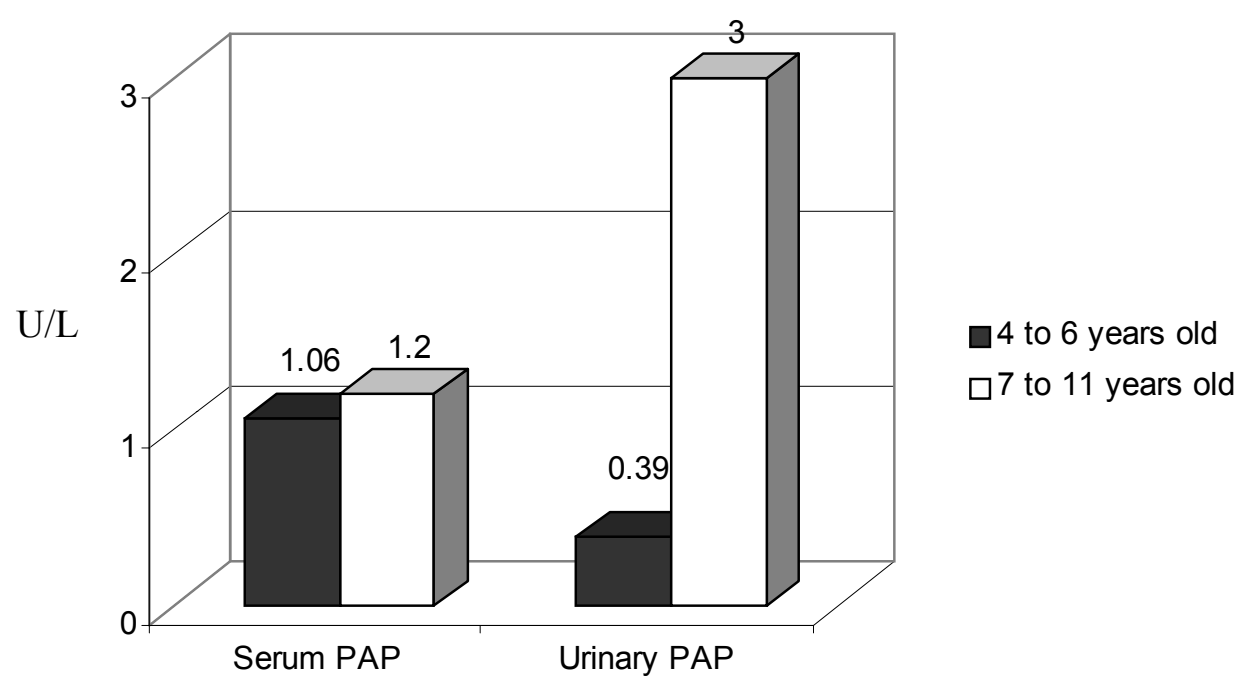

Figure 1. Serum and urinary prostatic acid phosphatase (PAP) (U/1) levels, according to age group in dogs

\footnotetext{
${ }^{4}$ Elecsys, Roche, Germany

${ }^{5}$ Elecsys total PSA immunoassay, 1731262, Roche, Germany
} 


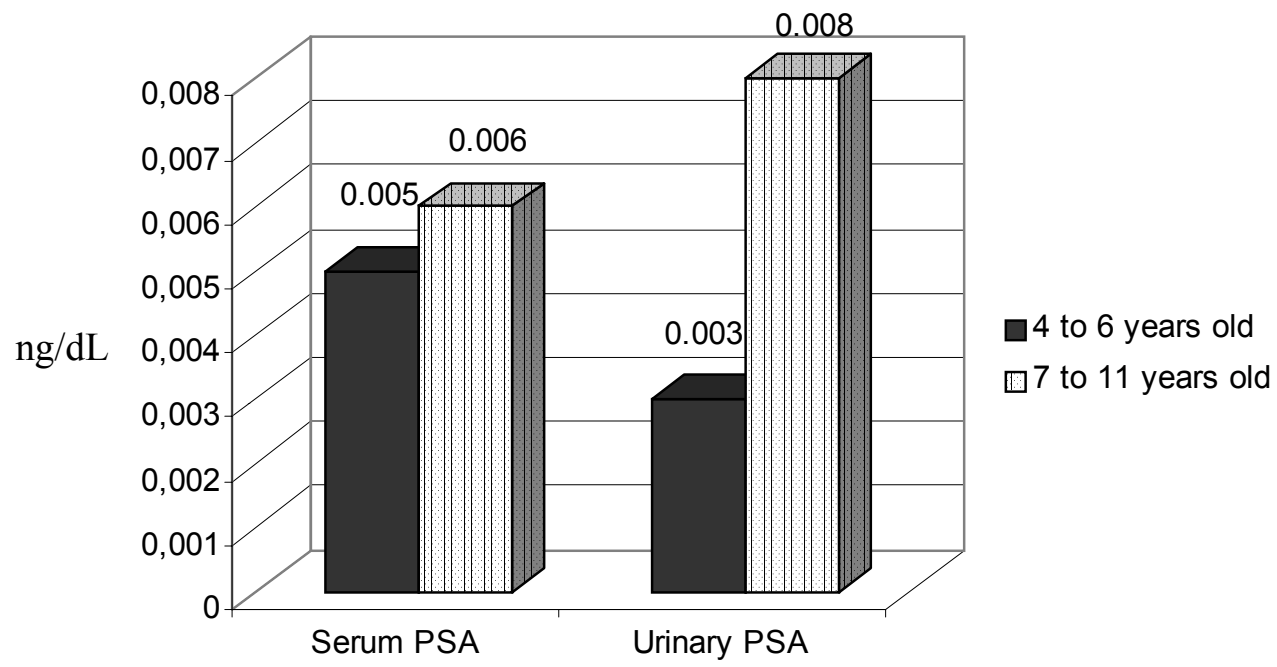

Figure 2. Serum and urinary prostatic specific antigen (PSA) (ng/dl) levels, according to age group in dogs

Table 2. Spearman's correlation coefficients according to variable combination $(\mathrm{n}=20 \mathrm{dogs})$

\begin{tabular}{lccc} 
& $\begin{array}{c}\text { Urinary } \\
\text { PAP }\end{array}$ & Serum PSA & $\begin{array}{c}\text { Urinary } \\
\text { PSA }\end{array}$ \\
\hline Serum & 0.18 & -0.10 & 0.19 \\
PAP & $(\mathrm{P}>0.05)$ & $(\mathrm{P}>0.05)$ & $(\mathrm{P}>0.05)$ \\
Urinary & & 0.03 & -0.07 \\
PAP & & $(\mathrm{P}>0.05)$ & $(\mathrm{P}>0.05)$ \\
Serum & & -0.30 \\
PSA & & $(\mathrm{P}>0.05)$ \\
\hline PAP - prostatic acid phosphatase; PSA - prostatic \\
specific antigen.
\end{tabular}

\section{DISCUSSION}

The average of urinary PAP of the animals in group 2 was high. Such fact was due to the high value obtained in the dosage of one of the animals (13.4 U/1).

According to Corazza et al. (1994), who studied PAP values in healthy dogs, as well as with BPH and prostatic adenocarcinoma, low concentrations of PAP do not exclude prostatic neoplasia, although higher values can suggest cancer.

In two groups of dogs (four to six years and seven to 11 years), Souza (1998) found $1.5 \pm 1.0 \mathrm{U} / 1$ and $1.3 \pm 1.6 \mathrm{U} / 1$ in PAP serum, respectively. Such values were very similar to those found in this current trial

In relation to urine and serum PSA dosage in dogs, data that could be used as comparative parameters for this variable were not found in the consulted literature. The obtained PSA values were inferior to those observed in humans with $\mathrm{BPH}$ (4 to $10 \mathrm{ng} / \mathrm{dl}$ ). Perhaps, as the methodology used in this work was with monoclonal antibodies raised against humans, the sensitivity of the test for dogs is weaker.

Association was not observed between serum and urinary values of PAP and PSA $(\mathrm{P}>0.05)$. In humans, there is a correlation between PAP and PSA serum and urinary values (White et al., 1992). Therefore, it would be important to evaluate those enzymes in the canine serum and urine. 


\section{CONCLUSIONS}

The study of this biological marker in canines should be better explored, as there is a probability of correlating the values obtained in this type of test, used routinely for humans, with the different prostatic affections of dogs. Further studies should be conducted to verify whether these proteins can be used as a diagnostic tool for canine prostatic affections, allowing an early diagnosis and, consequently, better prognosis.

\section{REFERENCES}

ALIVIZATOS, G.; DIMOPOULOS, A.; MITROPOULOS, D. et al. Efficacy of eight measures markers for diagnosis of prostatic carcinoma. Arch. Esp. Urol., v.45, p.269-272, 1992.

ARMBRUSTER, D.A. Prostate-specific antigen: biochemistry, analytical methods, and clinical application. Clin. Chem., v.39, p.181-195, 1993.

AUMÜLLER, G.; VEDDER, H.; ENDERLESCHMITT, U. et al. Cytochemistry and Biochemistry of Acid Phosphatases VII: Immunohistochemistry of canine prostatic acid phosphatase. Prostate, v.11, p.1-15, 1987.

AUS, G.; BERGDAHL, S.; HUGOSSON, J. et al. Influence of benign prostatic hyperplasia, testosterone and age on serum levels of prostate specific antigen. Scand. J. Urol. Nephrol., v.28, p.379-384, 1994.

BARSANTI, J.A.; FINCO, D.R Canine prostatic diseases. In: ETTINGER, S.J. Textbook of veterinary internal medicine. 3.ed. Philadelphia: W.B. Saunders, 1989. Chap.2, p.1859-1880.

CHRISTENSSON, A.; BJORK, T.; NILSSON, $O$. et al. Serum prostate specific antigen complexed to alfal-antichymotrypsin as an indicator of prostate cancer. J. Urol., v.150, p.100-105, 1993.

CORAZZA, M.; GUIDI, G.; ROMAGNOLI, S. et al. A. Serum total prostatic and non-prostatic acid phosphatase in healthy dogs and in dogs with prostatic diseases. J. Small Anim. Pract., v.35, p.307-310, 1994.

KARR, J.F.; KANTOR, J.A.; HAND, P.H. et al. The presence of prostatic-specific antigen related genes in primates and the expression of recombinant human prostate-specific antigen in a transfected murine cell line. Cancer Res., v.55, p.2455-2462, 1995.

LOWSETH, L.A.; GERLACH, R.F.; GILLETT, N.A. et al. Age-related in the prostate and testes of the beagle dog. Vet. Pathol., v. 37, p. 347-353, 1990.

MCENTEE, M.; ISAACS, I.; SMITH, C. Adenocarcinoma of the canine prostate: immunohistochemical examination for secretory antigens. Prostate, v.11, p.163-170, 1987.

SOUZA, F.F. Estudo da próstata canina pelo exame ultra-sonográfico, palpação retal, dosagens séricas de testosterona, 17 $\beta$-estradiol, fosfatase ácida prostática e antígeno específico prostático. 1998. 85f. Dissertação (Mestrado) Faculdade de Ciências Agrárias e Veterinárias, Universidade Estadual Paulista, Jaboticabal, SP.

STAMEY, T.A.; EKMAN, P.E.; BLANKENSTEIN, M.A. et al. Prostate-specific antigen as a serum marker for adenocarcinoma of the prostate. N. Engl. J. Med., v.317, p.909-916, 1987.

WATERS, D.J.; BOSTWICK, D.G. Prostatic intraepithelial neoplasia occurs spontaneously in the canine prostate. J. Urol., v.157, p.713-716, $1997 b$.

WATERS, D.J.; BOSTWICK, D.G. The canine prostate is a spontaneous model of intraepithelial neoplasia and prostate cancer progression. Anticancer Res., v.17, p.1467-1470, 1997a.

WHITE, R.W.V.; MEYERS, F.J.; SOARES, S.E. et al. Urinary prostate specific antigen levels: role in monitoring the response of prostate cancer to therapy. J. Urol., v.147, p.947951, 1992. 